\title{
Introduced European minnow Phoxinus phoxinus in alpine lakes may increase total mercury concentration in brown trout Salmo trutta
}

\author{
Reidar Borgstrom', Sigurd Rognerud', Sondre Meland,2, and Bjorn Olav Rosseland'
}

\begin{abstract}
Borgstrøm R, Rognerud S, Meland S and Rosseland BO. 2021. Introduced European minnow Phoxinus phoxinus in alpine lakes may increase mercury concentration in brown trout Salmo trutta. Fauna norvegica 41: 41-49.

In Norway, the cyprinid European minnow Phoxinus phoxinus has been spread far outside its previous natural distribution area, with lots of establishments in mountain lakes where brown trout Salmo trutta originally was the only fish species. We have analysed $\delta^{15} \mathrm{~N}$ and total mercury (THg) concentration in brown trout from eight lakes, situated between 1031 and 1244 m a. s. l. on the Hardangervidda mountain plateau, southern Norway. One of the lakes is inhabited by brown trout and European minnow, while in the other seven lakes, brown trout is the only fish species. $\delta^{15} \mathrm{~N}$ of brown trout were significantly higher in the population with co-existing European minnow, indicating a higher trophic position of brown trout in this population than in the allopatric populations, probably caused by piscivory, as indicated by frequent occurrence of European minnow in brown trout diet. The mercury concentrations in brown trout from this lake had values up to around $0.4 \mathrm{mg}$ THg per kg wet weight. The concentrations were significantly higher than in the lakes without European minnow, and together with the $\delta^{15} \mathrm{~N}$ values, indicating that translocation and establishment of European minnow may increase the trophic position of brown trout in previously allopatric populations, and thereby also increase the mercury level.
\end{abstract}

doi: 10.5324/fn.v41i0.3967. Received: 2021-02-12. Accepted: 2021-08-04. Published online: 2021-11-26. ISSN: 1891-5396 (electronic).

Keywords: THg concentration, trophic level, $\delta^{15} \mathrm{~N}$, piscivory, prey fish

1. Faculty of Environmental Sciences and Natural Resource Management, Norwegian University of Life Sciences, PO Box 5003, NO-1432 Ass, Norway

2. Norwegian Institute for Water Research (NIVA), Gaustadalléen 21, NO-0349 Oslo, Norway

Corresponding author: Reidar Borgstrøm

E-mail: reidar.borgstrom@nmbu.no

\section{INTRODUCTION}

A high number of small-sized fish species are spread over country borders or within a country, partly because they are used as live bait or introduced as food enhancement for local fish species. Typical examples are the spreading of redside shiner Richardsonius balteatus Richardson, 1836 in North America (Larkin \& Smith 1954; Johannes \& Larkin 1961), and the European minnow Phoxinus phoxinus Linnaeus, 1758 in Europe (Hesthagen \& Sandlund 1997, Museth et al. 2007). The European minnow is an indigenous species in south-eastern Norway and parts of northern Norway (Huitfeldt-Kaas 1918), but the species has been translocated to all counties during the previous century (Hesthagen \& Sandlund 1997), as well as brought in from other countries, as indicated by genetic analysis (Thaulow et al. 2014). Generally, brown trout (Salmo trutta Linnaeus, 1758) has been the only fish species in most high mountain lakes in southern Norway, where this species has been important for recreational, private household and commercial fishing (Sømme 1941; Qvenild 2004). During the last decades, however, European minnow has increased its distribution area in this mountain region by introductions, and it is now established in a high number of lakes formerly inhabited by brown trout only (Rognerud et al. 2003; Hesthagen \& Sandlund 1997;
Museth et al. 2007).

According to Braaten et al. (2018a) the atmospheric input of mercury $(\mathrm{Hg})$ to Norway is estimated to 3.3 tons annually, with a considerable retention in soil and lakes. Due to this long-range transport of mercury, catchments and lakes even in remote Arctic and high mountain areas are polluted with mercury (Rognerud \& Fjeld 2001; Rognerud et al. 2002; Berg et al. 2006; Rosseland et al. 2007; Jenssen et al. 2010; Braaten et al. 2017). At the same time introduced invertebrates and fish may increase the length of the food chain and result in elevated mercury levels in the top predator fishes (Cabana et al. 1994; Swanson et al. 2003). European minnow may feed on the same invertebrates as brown trout, and concurrently become part of brown trout diet (Museth et al. 2003), thus elevating the trophic position of brown trout, with increasing risk of obtaining higher total mercury (THg) concentrations (Rognerud et al. 2002). Eating of fish is the main source for exposure to mercury in humans, and due to the neurotoxic effects of mercury, fish consumption is of special concern for "groups at risk", especially pregnant women and prenatal and postnatal exposure to children (Myers et al. 2009; Okpala et al. 2017). The nitrogen stored in animals is enriched in the ${ }^{15} \mathrm{~N}$ isotope relative to the concentration in the food, and accordingly 
top predators such as piscivorous fish have the highest concentration of this nitrogen isotope. Accordingly, the ratio of the stable nitrogen isotopes ${ }^{15} \mathrm{~N}$ and ${ }^{14} \mathrm{~N}\left(\delta^{15} \mathrm{~N}\right)$ relative to a standard (atmospheric $\mathrm{N}_{2}$ ), and expressed per mil (\%), can be used as an estimate of trophic position (Cabana \& Rasmussen 1996, and references therein). On this background, we have analysed THg concentrations and $\delta^{15} \mathrm{~N}$ in brown trout from populations on the Hardangervidda mountain plateau in Norway, with two primary objectives; (i) examine the concentrations of total mercury and the trophic position (indicated by $\delta^{15} \mathrm{~N}$ ) of brown trout in lakes with and without coexisting European minnow, and (ii) explain the variation in $\mathrm{THg}$ concentrations, within and between fish populations, with respect to fish specific data (age, length), and trophic position.

\section{MATERIAL AND METHODS}

\section{The lakes and sampling procedures}

The study is based on data from eight natural lakes located on the Hardangervidda mountain plateau, in the southern part of Norway (Figure 1), of which seven of the lakes are inhabited by brown trout only, while lake Skaupsjøen is inhabited by brown trout and European minnow. This lake is situated $1158 \mathrm{~m}$ above sea level (a. s. 1.) on the northern part of the mountain plateau, just outside the Hardangervidda national park (Figure 1). It has a mean depth of only $2.1 \mathrm{~m}$, with many small islets over a large part of the $2.88 \mathrm{~km}^{2}$ lake area. The other lakes are situated between 1031 and $1244 \mathrm{~m}$ a. s. 1 (Table 1, Figure 1).

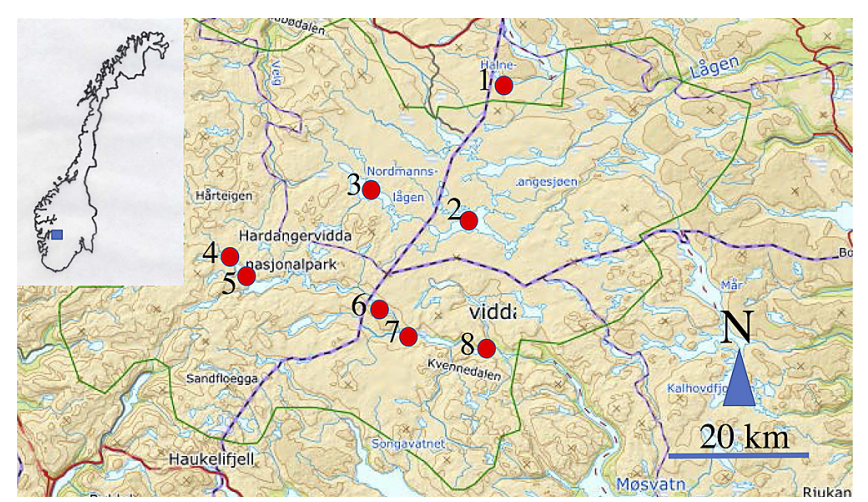

Figure I. Location of the studied lakes on the Hardangervidda mountain plateau, 1) Skaupsjøen, 2) Bjornesfjorden, 3) Nordmannslågen, in the catchment area of the river Numedalslågen, and 4) Kollsvatn, 5) Litlosvatn, 6) Sandvatn, 7) Gunnleiksbuvatn, 8) Vollevatn, all in the river Kvenna. Green line delimits Hardangervidda National park, and blue lines are county and municipality borders (Map source: Kartverket.no).
In 1973, European minnow was recorded for the first time in lakes just east of Skaupsjøen (Borgstrøm 1973). The species has since been recorded in several lakes in this area, including the large reservoir Halne (Rognerud et al. 2003), from which minnows have free access to the above-lying lake Skaupsjøen where the species forms an important part of brown trout diet (Rognerud et al. 2003; Borgstrøm 2009). The establishment of European minnow in the area is most probably a result of direct spreading by man (fishermen illegally using live bait), or indirectly being stocked together with brown trout from areas where minnows may have entered the brown trout rearing facilities (Hesthagen \& Sandlund 1997).

The annual precipitation on Hardangervidda declines from west towards east, illustrated by the snow depth range measured around 1 April 1943 - 2000 at the western lake, Litlosvatn (depth range 77 - 334 $\mathrm{cm}$ ), at lake Nordmannslågen (depth range $50-260 \mathrm{~cm}$ ) in central part, and at lake Skaupsjøen (depth range $40-190 \mathrm{~cm}$ ) in the northeastern part of the study area (Rognerud et al. 2003). Accordingly, airborne pollutants such as mercury are expected to be highest in the western and lowest in the eastern part of the mountain area. Analyses of water quality ( $\mathrm{pH}$, total organic carbon (TOC) and alkalinity) of the lakes have been performed by the Norwegian Institute for Water Research (NIVA) (Skjelkvåle \& Henriksen 1998; Rognerud et al. 2003). All lakes in our study are relatively shallow, oligotrophic, circum-neutral, with low acid neutralizing capacity, and TOC values in the range 0.3 $-1.5 \mathrm{mg} \mathrm{L}^{-1}$ (Table 1). In boreal lakes with TOC concentrations in the range $3.6-20.1 \mathrm{mg} \mathrm{L}^{-1}$, i.e., much higher than in lakes in the present study, a significant positive relationship between TOC concentration and mean fish THg concentration was found (Braaten et al. 2018b).

Brown trout was originally the only fish species on the Hardangervidda mountain area, being present here for at least 6-7,000 years (Indrelid 2014). Recreational and household fishing for brown trout takes place in all the studied lakes, and commercial fishing has been common in some of them (the lakes Skaupsjøen, Bjornesfjorden, Nordmannslågen). The brown trout from this area is mostly marketed as fermented trout ('rakfisk' in Norwegian), to a price around 40 Euro per kg. Due to low annual recruitment to the brown trout population in the lake Skaupsjøen, stocking with 1+ brown trout has been performed for several years. The lakes Nordmannslågen and Bjornesfjorden have been stocked mainly with summer old brown trout $(0+)$.

\section{Sampling and chemical analysis}

In August 2000-2002, brown trout were sampled by fleets of gillnets with different mesh sizes from the seven lakes where the species is still allopatric, and from the lake, Skaupsjøen, where brown trout co-exist with European minnow. Additional gillnetting of brown trout and European minnow was performed in the lake Skaupsjøen

Table I. Morphometric and water quality data of the studied lakes on the Hardangervidda mountain plateau (Data from Skjelkvåle \& Henriksen 1998; Rognerud et al. 2003).

\begin{tabular}{lccccccc}
\hline Lake & Altitude $(\mathrm{m})$ & Lake area $\left(\mathrm{km}^{2}\right)$ & Mean depth $(\mathrm{m})$ & Max. depth $(\mathrm{m})$ & $\mathrm{pH}$ & TOC $(\mathrm{mg} / \mathrm{L})$ & Alkalinity $(\mu \mathrm{eq} / \mathrm{L})$ \\
\hline Skaupsjøen & 1158 & 2.88 & 2.10 & 8 & 6.9 & 1.4 & 0.144 \\
Kollsvatn & 1182 & 0.63 & 6.5 & 13 & 6.7 & 0.7 & 0.067 \\
\hline Litlosvatn & 1172 & 1.51 & 10.2 & 25 & 6.6 & 0.3 & 0.054 \\
Sandvatn & 1112 & 1.58 & 2.55 & 13 & 6.8 & 0.4 & 0.096 \\
Gunnleiksbuvatn & 1076 & 1.27 & 2.9 & 12 & 6.8 & 0.8 & 0.062 \\
Vollevatn & 1031 & 1.54 & 2.9 & 18 & 6.7 & 0.8 & 0.067 \\
Bjornesfjorden & 1223 & 18.55 & 4.2 & 11 & 6.7 & 1.5 & 0.099 \\
Nordmannslågen & 1244 & 11.09 & 4.2 & 16 & 6.9 & 1.0 & - \\
\hline
\end{tabular}


Table 2. Summary statistics for the analysed brown trout and European minnow (number, length, age), sampled from eight lakes on the Hardangervidda mountain plateau in August 2000- 2002 and 2009.

\begin{tabular}{|c|c|c|c|c|c|c|c|c|}
\hline Lake & $\begin{array}{c}\text { Coordinates: } \\
\text { EU89, UTM33 }\end{array}$ & Fish species & $\begin{array}{l}\text { Sampling } \\
\text { year }\end{array}$ & $\begin{array}{l}\text { No. of } \\
\text { fish }\end{array}$ & $\begin{array}{l}\text { Length range } \\
(\mathrm{mm})\end{array}$ & $\begin{array}{l}\text { Mean length } \\
(\mathrm{mm}) \pm \mathrm{SD}\end{array}$ & Age range & Mean age \\
\hline \multirow[t]{3}{*}{ Skaupsjøen } & $6711135 \mathrm{~N} 99598 \mathrm{E}$ & Brown trout & 2001 & 16 & $175-520$ & $310 \pm 88$ & $3-13$ & $5.7 \pm 2.2$ \\
\hline & & “ & 2009 & 18 & $131-495$ & $275 \pm 112$ & $3-17$ & $6.1 \pm 3.3$ \\
\hline & & $\begin{array}{c}\text { European } \\
\text { minnow }\end{array}$ & 2009 & $14^{*}$ & $52-88$ & & $4-7$ & \\
\hline Kollsvatn & $6688405 \mathrm{~N} 62161 \mathrm{E}$ & Brown trout & 2001 & 21 & $145-482$ & $238 \pm 102$ & $3-15$ & $5.0 \pm 2.8$ \\
\hline Litlosvatn & $6685584 \mathrm{~N} 64681 \mathrm{E}$ & “ & 2001 & 18 & $155-410$ & $236 \pm 61$ & $3-10$ & $4.6 \pm 1.7$ \\
\hline Sandvatn & $6681071 \mathrm{~N} 83666 \mathrm{E}$ & “ & 2001 & 20 & $145-495$ & $303 \pm 106$ & $3-11$ & $6.0 \pm 2.1$ \\
\hline Gunnleiksbuvatn & $6678203 \mathrm{~N} 86571 \mathrm{E}$ & “ & 2001 & 15 & $135-535$ & $290 \pm 103$ & $3-11$ & $6.8 \pm 2.3$ \\
\hline Vollevatn & $6676567 \mathrm{~N} 97150 \mathrm{E}$ & “ & 2001 & 16 & $170-395$ & $313 \pm 59$ & $3-10$ & $6.8 \pm 1.8$ \\
\hline Nordmannslågen & $6695413 \mathrm{~N} 82899 \mathrm{E}$ & “ & 2001 & 14 & $210-380$ & $309 \pm 50$ & $4-7$ & $5.6 \pm 1.0$ \\
\hline Bjornesfjorden & $6690599 \mathrm{~N} 99824 \mathrm{E}$ & $"$ & 2000,2002 & 20 & $135-465$ & $357 \pm 87$ & $3-8$ & $6.4 \pm 1.6$ \\
\hline
\end{tabular}

*In total, length- and THg-data are available for 14 European minnows, of which 13 have been aged, and nine analysed with regard to stable isotopes of $\mathrm{N}$

in August 2009. Summary statistics for the sampled fish are given in Table 2. Length of the sampled brown trout and European minnow was measured in $\mathrm{mm}$, and otoliths were collected for age determination. A piece of bone- and skinless dorsal axial muscle tissue were removed from each brown trout, wrapped in aluminum foil, stored in polyethylene bags, and frozen, for later total mercury concentrations (THg) and stable isotope $\left(\delta^{15} \mathrm{~N}\right)$ analysis, following the EMERGE Fish protocol (Rosseland et al. 2001). Sampling from European minnow was done in approximately the same way, but due to the small size of the minnows, the whole fish was collected.

Analyses of the ratio between the stable isotope ${ }^{15} \mathrm{~N}$ and ${ }^{14} \mathrm{~N}$ ratio $\left(\delta^{15} \mathrm{~N}\right)$ and $\mathrm{THg}$ for fish sampled in 2009 were performed at the Isotope Laboratory, Faculty of Environmental Sciences and Natural Resource Management (MINA), Norwegian University of Life Sciences (NMBU). Samples from 2000-2002 were analysed for $\delta^{15} \mathrm{~N}$ at Institute for Energy Technology (IFE) at Kjeller, Norway, and $\mathrm{THg}$ analysed at Norwegian Institute of Water Research (NIVA). All these laboratories are certified and follow the same analysis procedures. For stable isotope analysis of nitrogen, thoroughly described by Jenssen et al. (2010), the muscle tissues of the brown trout and European minnows were homogenized and freeze-dried. Stable isotopic ratios of nitrogen $\left({ }^{15} \mathrm{~N} /{ }^{14} \mathrm{~N}\right)$ were determined by combusting the homogenized freeze-dried samples in a Flash Elemental Analyzer (EA), separating the combustion gases $\left(\mathrm{CO}_{2}\right.$ and $\left.\mathrm{N}_{2}\right)$ with a Poraplot $\mathrm{Q}$ column, and transferring them to a Finnigan DeltaPlus XP continuous-flow isotope ratio mass spectrometer (CF-IRMS). The isotopic ratio $\left({ }^{15} \mathrm{~N} /{ }^{14} \mathrm{~N}\right)$ was expressed as a delta-value: $\delta^{15} \mathrm{~N}(\%)$. The house standard of brown trout was measured at the beginning of each run and repeated regularly during a run, with an average analysed value at $13.20 \% \pm$ SD $0.06 \%$.

According to Cabana \& Rasmussen (1996), cross-system comparisons in $\delta^{15} \mathrm{~N}$ can be complicated due to differences in $\delta^{15} \mathrm{~N}$ at the base of the food chain, which increases markedly with the human population density in the lake watershed, likely reflecting the high $\delta^{15} \mathrm{~N}$ of human sewage. Accordingly, $\delta^{15} \mathrm{~N}$ should preferably have been corrected to a common bottom line, for example by use of the $\delta^{15} \mathrm{~N}$ in the snail Radix peregra (Müller, 1774) as a reference species for primary consumers, as suggested by Post (2002). However, we have no data from snails in all lakes, and therefore the analysed values have been used directly. In the catchment of the studied lakes, the local anthropogenic activity is very low, with no permanent residents, and with only a few cabins used primarily for fishing and hunting. At the lakes Litlosvatn and Nordmannslågen there are tourist cabins which are open for hikers in Easter and around 2.5 months each summer, but with strong restrictions on litter and sewage, and we consider the influence on $\delta^{15} \mathrm{~N}$ to be disregarded. In addition, the lakes in this study are situated at nearly the same elevation, and the background $\delta^{15} \mathrm{~N}$ is thus expected to be at the same level.

For THg analysis, described in Rognerud et al. (2002), approximately $1 \mathrm{~g}$ was digested in $20 \mathrm{~mL} 7 \mathrm{~N}$ nitric acid before being analysed for total $\mathrm{Hg}$ by cold vapour AAS (Perkin Elmer FIMS 400) equipped with a hydride generator. The detection limit was 0.005 $\mu \mathrm{g} \mathrm{g}^{-1}$ wet weight. The analyses were run in series of 30 samples, of which one was a standard reference and three were blanks. The standard reference was a fish homogenate (DORM 2, dogfish filet (of Squalus acanthias Linnaeus, 1758), a certified reference material from the National Research Council of Canada, Ottawa, and used at both laboratories.

\section{Age determination of fish}

The age of both brown trout and European minnow was determined by otoliths. The brown trout otoliths (sagitta) were broken through the center, and each otolith half were burnt (Power 1978). Thereafter, the burnt otolith halves were placed in a piece of modeling wax with the cut surface turned up, and soaked in propandiol, before age determination was performed under a stereomicroscope (Figure 2). The European minnow otoliths were placed whole in propandiol, and age determined against a black background under a stereomicroscope (Figure 2).

\section{Statistical analyses}

All descriptive statistics and statistical analyses were performed by the software JMP 16.0.0 (SAS Institute) and Canoco5 (v5.12, Ter Braak \& Šmilauer 2018). Assumption-free ANOVA, t-test, linear regression and multiple linear regression with forward selection were conducted by using different set-ups of Redundancy Analysis (RDA) combined with Monte Carlo permutation tests (Šmilauer \& Leps 2014). This approach is robust against violation of the assumption of a normal distribution of the modelled residuals in parametric tests. By using Monte Carlo permutation test, pseudo F-ratio calculated by 

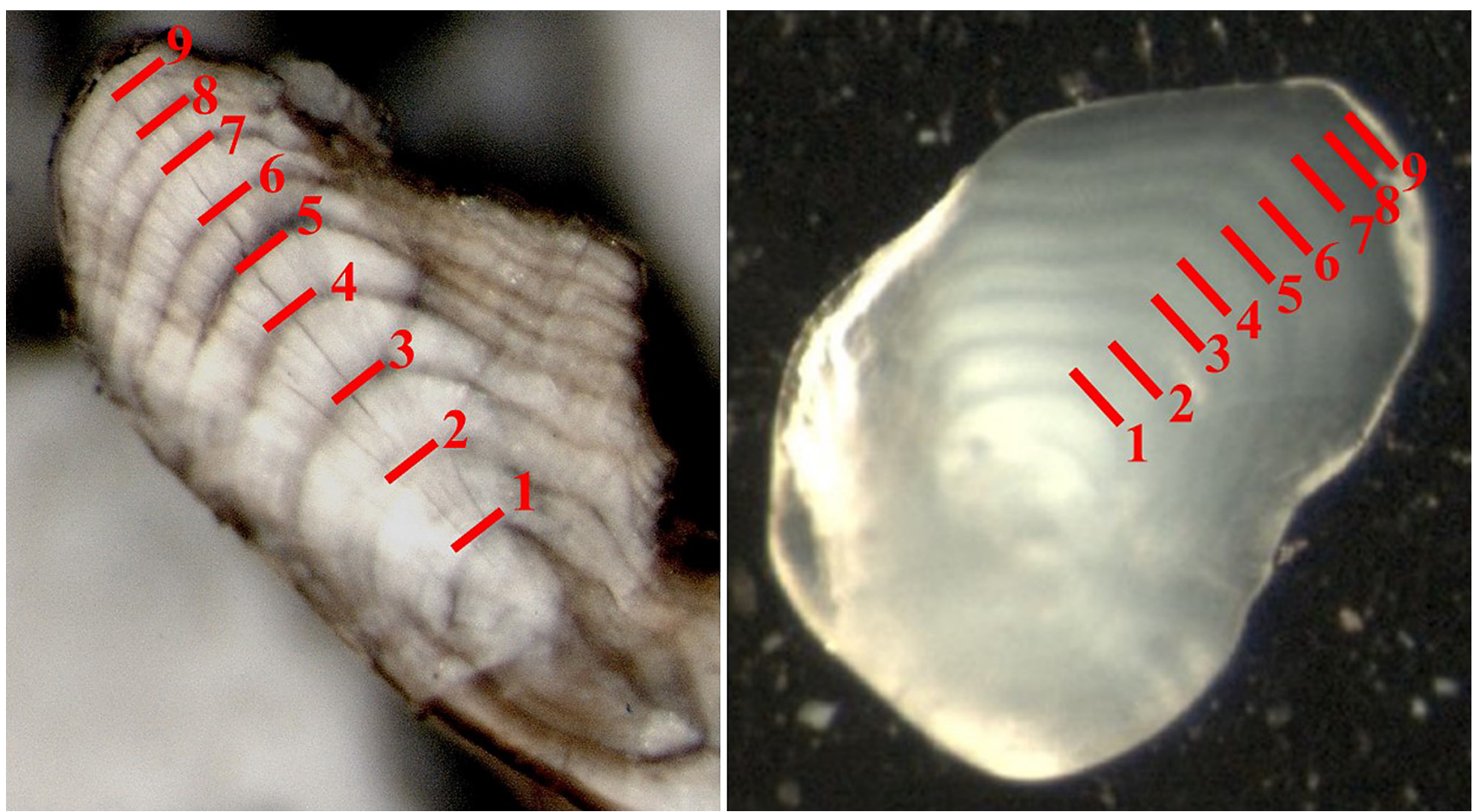

Figure 2. Broken and burnt otolith of a nine winters old brown trout from the lake Skaupsjøen (left), and a cleared, whole otolith of a nine winters old European minnow from the lake Øvre Heimdalsvatn (right), both sampled in August.

the existing data and corresponding p-values are derived. A total of 1999 permutations were conducted in each statistical test. Statistically significant level was set to $\mathrm{p}<0.05$.

\section{RESULTS}

\section{Mercury concentrations and $\delta^{15} \mathrm{~N}$ level in brown trout and European minnow}

The statistical tests revealed no differences in length (pseudo- $\mathrm{F}<0.1$, $\mathrm{p}>0.05$ ) and age (pseudo-F $<1, \mathrm{p}>0.05$ ) of brown trout between the allopatric populations and the sympatric population (Lake Skaupsiøen) (Figure 3). In contrast, the concentrations of THg were significantly higher in brown trout from the lake Skaupsjøen compared to brown trout from the other lakes (pseudo-F=142, $\mathrm{p}<0.001$ ). The $\mathrm{THg}$ concentrations in brown trout from the lake Skaupsjøen were in the range $0.02-0.41 \mathrm{mg} / \mathrm{kg}$ with mean value $0.13(\mathrm{SD}= \pm 0.08)$, while in the other lakes with allopatic brown trout the concentrations were in the range $0.01-0.12 \mathrm{mg} / \mathrm{kg}$, with mean value $0.04(\mathrm{SD}= \pm 0.02)$. Likewise, there was a significant difference in uncorrected $\delta^{15} \mathrm{~N}$ values between allopatric brown trout and sympatric brown trout (pseudo- $\mathrm{F}=232$, $\mathrm{p}<0.001$ ). To correct for variation in THg data attributed to age, length and uncorrected $\delta^{15} \mathrm{~N}$ in the statistical tests between the different populations (i.e. allopatric vs. sympatric), we performed a partial RDA (pRDA). The pRDA revealed a statistically significant difference between the two population types ( $\mathrm{pseudo}-\mathrm{F}=28.5, \mathrm{p}<0.001$ ). However, the explained variation ascribed to population type dropped from $47 \%$ to $15 \%$ after the correction.

In European minnow, the concentration of $\mathrm{THg}$ was in the range $0.05-0.14 \mathrm{mg} / \mathrm{kg}$, with a mean value $0.09(\mathrm{SD}= \pm 0.02)$. Even though there was no statistically significant difference between the two species ( $p$ seudo-F=3.1, $>>0.05$ ), the variation in THg concentrations was much greater in brown trout compared to European minnow (Figure 4). The variation in uncorrected $\delta^{15} \mathrm{~N}$ was also apparently
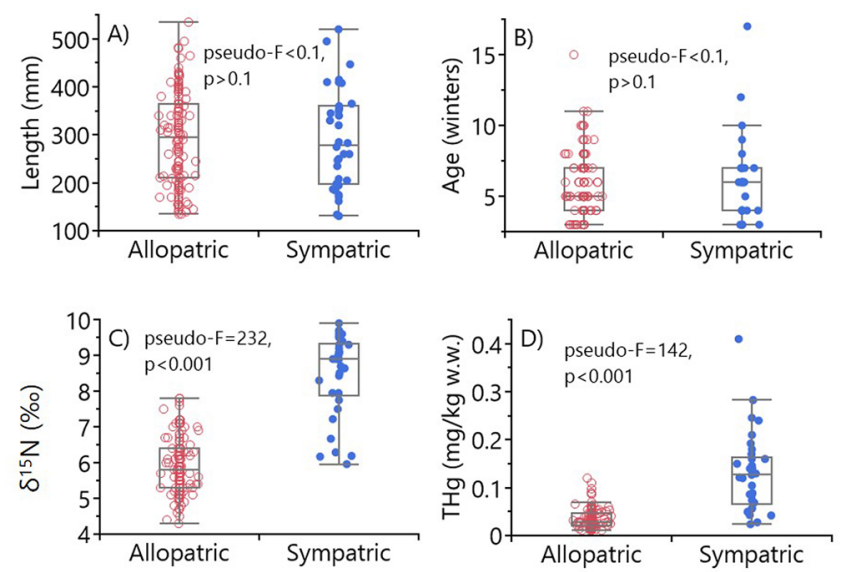

Figure 3. Boxplot showing the distribution of the variables length, age, $\delta^{15} \mathrm{~N}$ and THg in brown trout from the allopatric brown trout populations (in the lakes Bjornesfjorden, Nordmannslågen, Kollsvatn, Litlosvatn, Sandvatn, Gunnleiksbuvatn, and Vollevatn), and from the sympatric brown trout population in the lake Skaupsjøen. Statistical outputs from the RDA and Monte Carlo permutation tests (1999 permutations) performed on the two population categories are displayed in each panel.
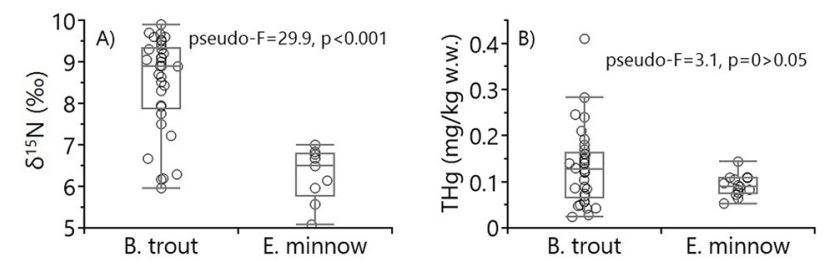

Figure 4. Boxplot showing the distribution of $\delta^{15} \mathrm{~N}$ and $\mathrm{THg}$ in brown trout and European minnow from Lake Skaupsjøen. Statistical outputs from the RDA and Monte Carlo permutation tests (1999 permutations) performed on the two species are displayed in each panel. 


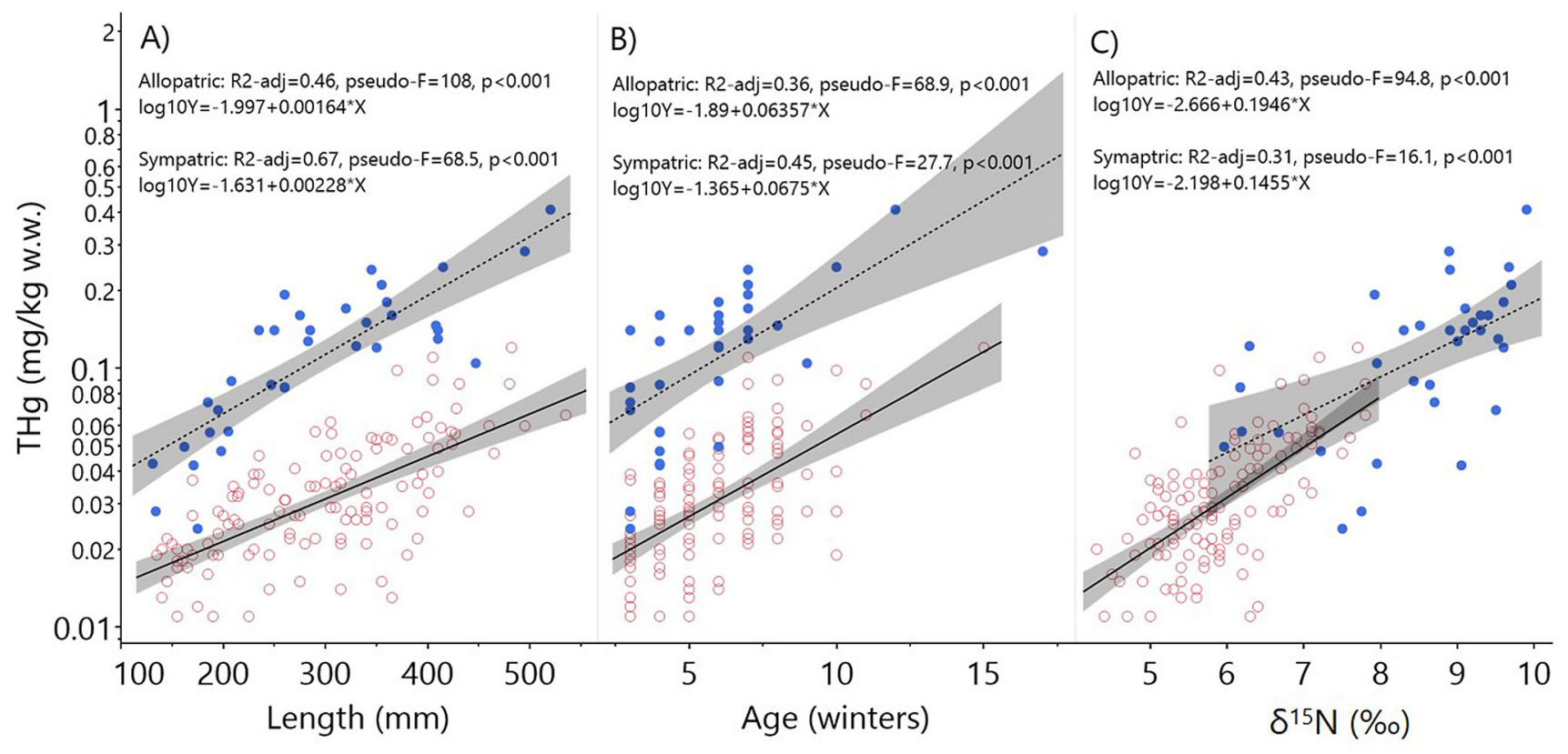

Figure 5. Total mercury concentration (THg) in allopatric (red open circles) and sympatric (blue closed circles) brown trout in relation to length (A), age (B), and $\delta^{15} \mathrm{~N}(\mathrm{C})$. The THg concentration is presented on a logarithmic scale. Fitted regression lines with $95 \%$ confidence intervals for each population are displayed in grey. Statistical outputs from the RDA and Monte Carlo permutation tests (1999 permutations) are displayed in each panel.

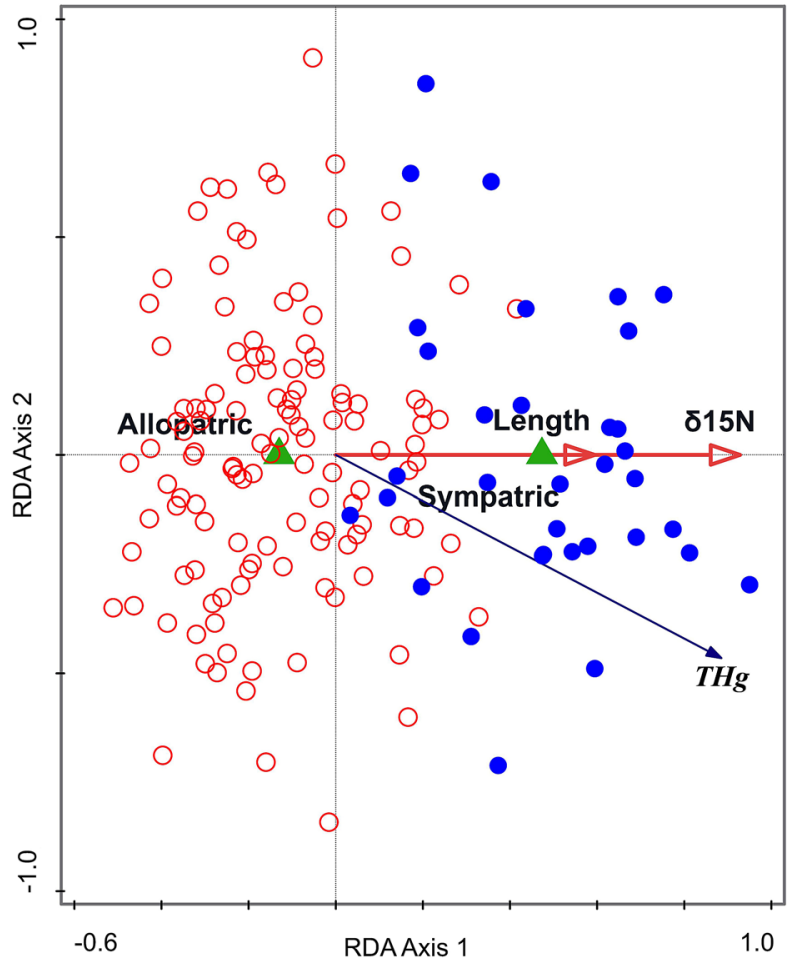

Figure 6. Ordination plot showing the output of the multiple regression with forward selection. Only the statistically significant variables are included. In brief, individual samples of brown trout from allopatric and sympatric populations are displayed with red and blue circles, respectively. The arrows points in the direction of increasing concentration of THg (black arrow) and increasing length and $\delta 15 \mathrm{~N}$ (red arrows). The sharp angle between the THg arrow and the arrows of length and $\delta 15 \mathrm{~N}$ indicate a positive correlation between the variables, i.e. larger fish and higher $\delta 15 \mathrm{~N}$ are associated with higher levels of THg. In addition, population type used as nominal variable (green triangles) and the individual samples from the allopatric and the sympatric populations are also clearly separated along the first RDA axis and along the THg arrow, indicating that brown trout from the sympatric population have in general higher concentrations of THg. greater in brown trout compared to European minnow, and the difference between the two species was significant (pseudo- $\mathrm{F}=29.9$, $\mathrm{p}<0.001$ ) (Figure 4). In the lake Skaupsjøen, the mean $\delta^{15} \mathrm{~N}$ in brown trout was $8.47 \%$, and in European minnow $6.28 \%$, while in brown trout from the allopatric populations mean $\delta^{15} \mathrm{~N}$ was $5.92 \%$.

The age, length and uncorrected $\delta^{15} \mathrm{~N}$ explained $36 \%$ $\left(\mathrm{R}^{2}\right.$-adjusted $=0.36$, pseudo- $\left.\mathrm{F}=68.9, \mathrm{p}<0.001\right), 46 \%\left(\mathrm{R}^{2}\right.$-adjusted $=0.46$, pseudo- $\mathrm{F}=108, \mathrm{p}<0.001)$ and $43 \%\left(\mathrm{R}^{2}\right.$-adjusted $=0.43$, pseudo- $\mathrm{F}=94.8$, $\mathrm{p}<0.001$ ) of the observed variation in THg in the allopatric brown trout populations, respectively (Figure 5). In the sympatric population, the age, length and uncorrected $\delta^{15} \mathrm{~N}$ explained $45 \%\left(\mathrm{R}^{2}\right.$-adjusted $=0.45$, pseudo- $\mathrm{F}=27.7, \mathrm{p}<0.001), 67 \%\left(\mathrm{R}^{2}\right.$-adjusted $=0.67$, pseudo- $\mathrm{F}=68.5$, $\mathrm{p}<0.001)$ and $31 \%\left(\mathrm{R}^{2}\right.$-adjusted $=0.31$, pseudo- $\left.\mathrm{F}=16.1, \mathrm{p}<0.001\right)$ of the observed variation in $\mathrm{THg}$, respectively. We also conducted a multiple regression where fish from both the allopatric and sympatric populations were included. Forward selection was applied to determine the best model to describe the observed variation. In addition to the numerical explanatory variables age, length and uncorrected $\delta^{15} \mathrm{~N}$, we included population type (i.e. allopatric/sympatric) as a nominal variable. The overall best model captured $78 \%\left(\mathrm{R}^{2}\right.$-adjusted $=0.78$, pseudo-F=140, $\mathrm{p}<0.001$ ) of the observed THg variation, and consisted of the explanatory variables uncorrected $\delta^{15} \mathrm{~N}$, length and population type. The output is displayed in the ordination plot in Figure 6. In all the regression models, a clear separation between the allopatric brown trout populations and the sympatric brown trout population from Lake Skaupsjøen was evident.

The amount of data on European minnow is substantially lower compared with the brown trout data, and the uncertainties in the regression models performed on the European minnow are higher. As for brown trout, there were apparently positive relationships between the THg concentrations and fish age, length and uncorrected $\delta^{15} \mathrm{~N}$ (Figure 7). However, only age was statistically significant $\left(\mathrm{R}^{2}\right.$-adjusted $=0.39$, pseudo- $\left.\mathrm{F}=8.5, \mathrm{p}<0.05\right)$. 


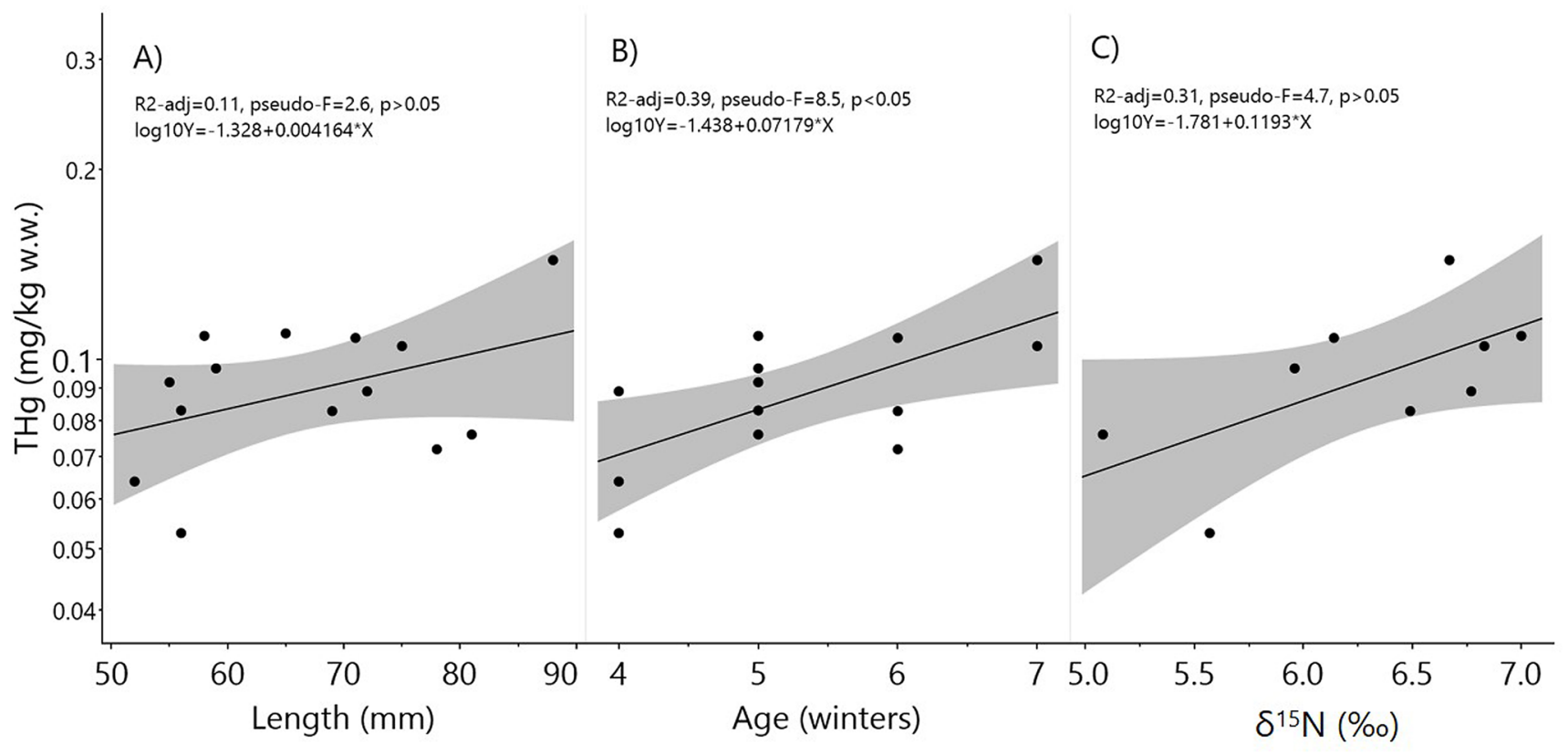

Figure 7. Total mercury concentration (THg) in European minnow from Lake Skaupsjøen captured in 2009 in relation to age (A), length (B), and $\delta^{15} \mathrm{~N}$ (C). The THg concentration is presented on a logarithmic scale. Fitted regression lines with $95 \%$ confidence intervals are displayed in grey. Statistical outputs from the RDA and Monte Carlo permutation tests (1999 permutations) are displayed in each panel.

\section{DISCUSSION}

The studied lakes are all low-productive, with low total organic carbon (TOC) values and nearly similar high $\mathrm{pH}$-values and alkalinity, and with minimal human activity in the catchment areas of all the lakes. However, the mean THg concentration in brown trout from Skaupsjøen was around three times higher than in brown trout from the allopatric populations. Factors causing mercury contamination in fish include bioavailability of methylmercury, and a food web that enhances bioaccumulation (Cabana et al. 1994; Gorski et al. 2003; Swanson et al. 2003). For instance, brown trout in the lake Mjøsa feed to a large extent on smelt Osmerus eperlanus (Linnaeus, 1758) and cisco Coregonus albula Linnaeus, 1758 (Kjellberg \& Sandlund 1983; Sandlund \& Næsje 1992), resulting in mercury concentrations exceeding $1 \mathrm{mg}$ per kg w.w, and increasing with size and age (Fjeld \& Rognerud 2002). The age of fish together with trophic position may therefore be significant predictors of mercury bioaccumulation (McIntyre \& Beauchamp 2007), as also indicated in the present study.

Introduced freshwater fish and invertebrate species may restructure food webs and cause major ecological changes, often at the expense of local species (Langeland 1981; Lasenby et al. 1986; Miller 1989; Spencer et al. 1991; Kolar \& Logde 2002; Baxter et al. 2004). The crustaceans Gammarus lacustris G. O. Sars, 1863 and Lepidurus arcticus (Pallas, 1793) are among the most important food items for brown trout in lakes on Hardangervidda (L'Abée-Lund \& Sægrov 1991; Borgstrøm 2016; Qvenild et al. 2020), as well as in other mountain areas in southern Norway (Aass 1969; Lien 1978). European minnow feed on the same prey species (Borgstrøm et al. 1985; Museth et al. 2010), also indicated by the $\delta^{15} \mathrm{~N}$ of the analysed European minnow from lake Skaupssjøen being nearly in the same range as found for brown trout in the analysed allopatric populations. Because European minnow is included in the diet of brown trout in the lake Skaupsjøen (Rognerud et al. 2003; Borgstrøm 2009), the food web becomes longer, and this is probably the main reason for the elevated mercury concentrations in individuals from this population. In aquatic food webs, the mean $\delta^{15} \mathrm{~N}$ of a consumer is typically enriched by 3-4 \%o relative to its diet (Vander Zanden \& Rasmussen 1999; Post 2002; and references therein). The difference was ca 2.55 $\%$ (unadjusted values) between brown trout from Skaupsjøen (mean $\delta^{15} \mathrm{~N}=8.47 \%$ ) and brown trout from the allopatric populations (mean $\delta^{15} \mathrm{~N}=5.92 \%$ ), i.e., less than one trophic level, indicating a mixed diet of brown trout from the lake Skaupsjøen, consisting of both invertebrates and minnows. In a similar fish community, with brown trout and European minnow, in the Norwegian subalpine lake, Øvre Heimdalsvatn (1095 m a. s. 1.) on the eastern slope of the Jotunheimen mountains, European minnow was mainly preyed upon during the minnow spawning period, i.e., in June-July (Lien 1981; Museth et al. 2003, Jenssen et al. 2010), probably a result of higher vulnerability of minnows at this time. Although the THg concentration in European minnow from the lake Øvre Heimdalsvatn was even higher than in the lake Skaupsjøen (range $0.014-0.16 \mathrm{mg} / \mathrm{kg}$ w.w) (Jenssen et al. 2010), the average THg in brown trout was low $(0.05 \mathrm{mg} / \mathrm{kg}$ w.w.). The average $\delta^{15} \mathrm{~N}$ in brown trout was $6.5 \%$ (Jenssen et al. 2010), i.e., indicating a lower trophic level than in the lake Skaupsjøen, probably reflecting a lower total consumption of minnows. Both the $\delta^{15} \mathrm{~N}$ and THg concentration were nevertheless higher in brown trout from the lake Øvre Heimdalsvatn than in brown trout from the allopatric populations included in our study. This may illustrate the effect on the mercury contamination in a piscivore as a result of the actual annual quantity of prey fish in the diet.

Seasonal studies of brown trout diet in the lake Skaupsjøen have not been performed, but minnows were an important part in both August 2009 (Borgstrøm 2009), and August 2001 (Rognerud et al. 2003), i.e., after the spawning season of minnows. The lakes Øvre Heimdalsvatn and Skaupsjøen differ in morphometry, with Skaupsjøen being very shallow, with lots of islets, probably increasing the availability of minnows to brown trout in this lake in comparison with the conditions in the lake Øvre Heimdalsvatn. Predation on minnows, and thereby the transfer of mercury to brown trout, may according to these examples show considerable variations between lakes, most probably depending on availability of minnows as prey for 
brown trout. The results from the lake Skaupsjøen can consequently not be asserted to all localities with brown trout and European minnow, but still be a predictor of the risk of mercury contamination in brown trout following establishment of European minnow in shallow lakes in this mountain region.

In addition to elevated mercury concentrations in brown trout after establishment of European minnow, both brown trout and European minnow feed on the same invertebrates (Borgstrøm et al. 1985; Museth et al. 2010), thus being potential competitors. In the lake Skjerjavatn, also on the Hardangervidda mountain plateau, annual harvest of brown trout was around $450 \mathrm{~kg}(2.9 \mathrm{~kg} / \mathrm{ha})$ previous to European minnow introduction (Taugbøl et al. 2002). After establishment of European minnow in the 1980ies, large shoals of minnows could be observed in shallow water, as well as in the spawning and rearing habitats of brown trout in the streams. In 1995 the brown trout population had become heavily reduced, and by a corresponding gillnet effort as used previously, the annual harvest was reduced to $60 \mathrm{~kg}$ (Taugbøl et al. 2002). This change in brown trout population density was probably a combined effect of competition and reduced annual recruitment to the brown trout population, following the European minnow establishment, as also indicated by studies in the lake, Øvre Heimdalsvatn (Borgstrøm et al. 2010; Brittain et al. 2019).

By introducing a new species of fish which can act as a prey for piscivore species in the same lake, the risk of increase in environmental contaminants like mercury in the top predator is high. Although the level of THg in the sympatric brown trout population in Skaupsjøen was not extremely high, the levels in old fish were still above the advisory levels for "consumers at risk", i.e., pregnant and lactating women and young children. European Food Safety Authority (EFSA) (2018) has set a Tolerable Weekly Intake (TWI) of organic mercury (near $100 \%$ in fish) to $1.3 \mu \mathrm{g} / \mathrm{kg}$ body weight, instead of a former use of mercury concentration in the fish filet. Norwegian Scientific Committee for Food and Environment (VKM) uses the same TWI-level, and in addition categorized the concentrations in fish filet as either "low" $(<0.051 \mathrm{mg} \mathrm{Hg} / \mathrm{kg})$ or "high" $(>0.33 \mathrm{mg} \mathrm{Hg} / \mathrm{kg})$. A $150 \mathrm{~g}$ weekly fish meal of category "high" will accordingly exceed the TWI level (Amlund et al. 2019). With a level of up to $0.41 \mathrm{mg} \mathrm{THg} /$ $\mathrm{kg}$ in brown trout from Skaupsjøen, it is clearly in the category "high", demonstrating a risk for the most sensitive consumer group. This also illustrate a need for further studies in mountain lakes with introduced prey fish species to establish local food advisory levels.

\section{CONCLUSION}

In addition to reduced brown trout production, the establishment of European minnow in mountain lakes formerly inhabited by allopatric brown trout may result in increased mercury contamination of brown trout, causing a possible health risk for those who use such fish regularly in their household. Thus, the European minnow-brown trout interaction revealed in the lake Skaupsjøen may illustrate the risk connected to the extensive spreading and establishment of European minnow in mountain areas.

\section{ACKNOWLEDGEMENT}

This study has been part of a formerly research project on brown trout on the Hardangervidda mountain plateau, financed by the Norwegian
Directorate for Nature Management (DN), EBL-Kompetanse, Statskog SF, Statkraft SF, County governor of Telemark, Eidfjord municipality, Eidfjord, Odda, and Ullensvang mountain boards, Interessentskapet Laagefjeld, and Norwegian Institute of Water Research (NIVA), which all are acknowledged. We also want to acknowledge the assistance of Anders Vaksdal, Tore Qvenild, and Åsmund Tysse in sampling of brown trout from some of the lakes, and the former Department of Ecology and Natural Resource Management, Norwegian University of Life Sciences, for economic support for the sampling and analysis conducted in 2009. Thanks are also due to the anonymous referees for their comments and suggestions for improving the manuscript.

\section{REFERENCES}

Aass P. 1969. Crustacea, especially Lepidurus arcticus Pallas, as brown trout food in Norwegian mountain reservoirs. Report Institute of Freshwater Research Drottningholm 49: 183-201.

Amlund H, Rakkestad KE, Ruus A, Starrfelt J, Beyer J, Brantsæter AL, Bremer S, Sundstøl Eriksen G, Mariussen E, Samdal IA, Thomsen C, Knutsen HK. 2019. Scenario calculations of mercury exposure from fish and overview of species with high mercury concentrations. Opinion of the Panel on Contaminants of the Norwegian Scientific Committee for Food and Environment. VKM report 2019:3. Oslo, Norway. Norwegian Scientific Committee for Food and Environment (VKM), 220 p. ISBN: 978-82-8259-319-9, ISSN: 2535-4019.

Baxter CV, Fausch KD, Murakami M, Chapman PL. 2004. Fish invasion restructures stream and forest food webs by interrupting reciprocal prey subsidies. Ecology 85: 2656-2663. doi: 10.1890/04-138.

Berg T, Fjeld E, Steinnes E. 2006. Atmospheric mercury in Norway: Contributions from different sources. Science of the Total Environment 368: 3-9. doi: 10.1016/j.scitotenv.2005.09.059.

Borgstrøm, R. 1973. Spredning av ørekyt. Jakt Fiske Friluftsliv 102 (12): 28-29.

Borgstrøm R. 2009. Aurebestanden i Skaupsjøen. Fagrapport fiskeforvaltning i høgfjellet 1 (1): 1-11. Department of Ecology and Natural Resource Management, Norwegian University of Life Sciences. https://static02.nmbu.no/mina/ansatte/reidbo/fr0903.pdf

Borgstrøm R. 2016. Auren på Hardangervidda er sterkt påverka av klimatilhøve. Naturen 140: 147-155. doi: 10.18261/issn.1504-31182016-04-02.

Borgstrøm R, Garnås E, Saltveit SJ. 1985. Interactions between brown trout, Salmo trutta (L.) and minnow, Phoxinus phoxinus (L.), for their common prey, Lepidurus arcticus (Pallas). Verhandlungen Internationale Vereinigung für Limnologie 22: 2548-2552. doi: 10.1080/03680770.1983.11897721.

Borgstrøm R, Museth J, Brittain JE. 2010. The brown trout (Salmo trutta) in the lake, Øvre Heimdalsvatn: long-term changes in population dynamics due to exploitation and the invasive species, European minnow (Phoxinus phoxinus). Hydrobiologia 642: 81-91. doi: 10.1007/ s10750-010-0161-7.

Braaten HFV, Åkerblom S, de Wit HA, Skotte G, Rask M, Vuorenmaa J, Kahilainen KK, Malinen T, Rognerud S, Lydersen E, Amundsen PA, Kashulin N, Kashulina T, Terentyev P, Christensen G, Jackson-Blake L, Lund E, Rosseland BO. 2017. Spatial and temporal trends of mercury in freshwater fish in Fennoscandia (1965-2015). ICP Waters report 132/2017. 70 p. ISBN 978-82-577-6914-7. NIVA-report ISSN 1894-7948

Braaten HFV, de Wit H, Larssen T, Poste A. 2018b. Mercury in fish from Norwegian lakes: The complex influence of aqueous organic carbon. Science of the Total Environment 627: 341-348. doi: 10.1016/j. scitotenv.2018.01.252.

Braaten HFV, Gundersen CB, Sample JE, Selvik JR, de Wit H. 2018a. Atmospheric deposition and lateral transport of mercury in Norwegian drainage basins: A mercury budget for Norway. NIVA-Rapport 7310. 45 p. ISBN 978-82-577-7045-7. 
Brittain JE, Borgstrøm R, Bremnes T, Håland S, Mjelde M, Nilssen JP, Skjelbred B. 2019. Øvre Heimdalsvatn - økologisk langtidsovervåking. Naturhistorisk museum, University of Oslo, Rapport 84: 1 - $64+$ attachment. ISSN nr. 1891-8050. ISBN nr. 978-82-7970-108-8.

Cabana G, Rasmussen JB. 1996. Comparison of aquatic food chains using nitrogen isotopes. Proceedings of the National Academy of Sciences USA 93: 10844-10847.

Cabana G, Tremblay A, Kalff J, Rasmussen JB. 1994. Pelagic food chain structure in Ontario lakes: A determinant of mercury levels in lake trout (Salvelinus namaycush). Canadian Journal of Fisheries and Aquatic Sciences 51: 381-389. doi: 10.1139/f94-039.

European Food Safety Authority (EFSA) 2018. Panel on Contaminants in the Food Chain (CONTAM); Scientific Opinion on the risk for public health related to the presence of mercury and methylmercury in food. EFSA Journal 2012; 10 (12): 2985. 241 p. Updated 2018-04-10. doi: 10.2903/j.efsa.2012.2985.

Fjeld E, Rognerud S. 2002. Kvikksølv i storørret og -røye i norske innsjøer, 2000-2001. NIVA Rapport 4502-02: 1 - 42.

Gorski PR, Cleckner LB, Hurley JP, Sierszen ME, Armstrong DE. 2003. Factors affecting enhanced mercury bioaccumulation in inland lakes of Isle Royale National Park, USA. The Science of the Total Environment 304: 327-348. doi: 10.1016/S0048-9697(02)00579-x.

Hesthagen T, Sandlund OT. 1997. Endringer i utbredelse av ørekyt i Norge: årsaker og effekter. NINA Fagrapport 013: 1-16. ISSN $0805-$ 469X ISBN 82-426-0804-0

Huitfeldt-Kaas H. 1918. Ferskvandsfiskenes utbredelse og indvandring Norge. Kristiania, Norway. Centraltrykkeriet, 106 p + figures.

Indrelid S. 2014. Oppdagelser på Hardangevidda. Kvinnherad, Norway. Nord, 222 p. ISBN 978-82-7326-108-3.

Jenssen MTS, Borgstrøm R, Salbu B, Rosseland BO. 2010. The importance of size and growth rate in determining mercury concentrations in European minnow (Phoxinus phoxinus) and brown trout (Salmo trutta) in the subalpine lake, Øvre Heimdalsvatn. Hydrobiologia 642: 115-126. doi: 10.1007/s10750-010-0156-4.

Johannes RE, Larkin PA. 1961. Competition for food between redside shiners (Richardsonius balteatus) and rainbow trout (Salmo gairdneri). Journal of Fisheries Research Board of Canada 18: 203-220. doi: 10.1139/f61-015.

Kjellberg G, Sandlund OT. 1983. Næringsrelasjoner i Mjøsas pelagiske økosystem. DVF-Mjøsundersøkelsen 6: 1-61.

Kolar CS, Lodge DM. 2002. Ecological predictions and risk assessment for alien fishes in North America. Science 298: 1233-1236. doi: 10.1126/science.1075753.

L'Abée-Lund JH, Sægrov H. 1991. Resource use, growth and effects of stocking in alpine brown trout, Salmo trutta L. Aquaculture and Fisheries Management 22: 519-526. doi: 10.1111/j.1365-2109.1991. tb00765.x.

Langeland A. 1981. Decreased zooplankton density in two Norwegian lakes caused by predation of recently introduced Mysis relicta. Proceedings International Association of Theoretical and Applied Limnology 21: 926-937. doi: 10.1080/03680770.1980.11897112.

Larkin PA, Smith SB. 1954. Some effects of introduction of the redside shiner on the Kamloops trout in Paul Lake, British Columbia. Transactions of the American Fisheries Society 83: 161-175. doi: 10.1577/1548-8659(1953)83\%5b161:SEOIOT\%5d2.0.CO;2.

Lasenby DC, Northcote TG, Fürst M. 1986. Theory, practice and efforts of Mysis relicta introductions to North America and Scandinavian lakes. Canadian Journal of Fisheries and Aquatic Sciences 43: 1277 1284. doi: 10.1139/f86-158.

Lien L. 1978. The energy budget of the brown trout population of Øvre Heimdalsvatn. Ecography 1: 279-300.

Lien L. 1981. Biology of the minnow Phoxinus phoxinus and its interactions with brown trout Salmo trutta, in Øvre Heimdalsvatn, Norway. Ecography 4: 191-200.

McIntyre JK, Beauchamp DA. 2007. Age and trophic position dominate bioaccumulation of mercury and organochlorines in the food web of
Lake Washington. Science of the Total Environment 372: 571-584. doi: 10.1016/j.scitotenv.2006.10.035.

Miller DJ. 1989. Introductions and extinction of fish in the African Great lakes. Trends in Ecology and Evolution 4: 56-59. doi: 10.1016/01695347(89)90145-6.

Museth J, Borgstrøm R, Hame T, Holen LÅ. 2003. Predation by brown trout: a major mortality factor for sexually mature European minnows. Journal of Fish Biology 62: 692-705. doi: 10.1046/j.10958649.2003.00059.x.

Museth J, Hesthagen T, Sandlund OT, Thorstad EB, Ugedal O. 2007. The history of the minnow Phoxinus phoxinus (L.) in Norway: from harmless species to pest. Journal of Fish Biology 71 (Supplement D): 184-195. doi: 10.1111/j.1095-8649.2007.01673.x.

Museth J, Borgstrøm R, Brittain JE. 2010. Diet overlap between introduced European minnow (Phoxinus phoxinus) and young brown trout (Salmo trutta) in the lake, Øvre Heimdalsvatn: a result of abundant resources or forced niche overlap? Hydrobiologia 642: 93-100. doi: 10.1007/s10750-010-0162-6.

Myers, GJ, Thurston SW, Pearson AT, Davidson PW, Cox C, Shamlaye CF, Cernichiari E, Clarkson TW. 2009. Postnatal exposure to methyl mercury from fish consumption: A review and new data from the Seychelles Child Development Study. NeuroToxicology 30: 338-349. doi: 10.1016/j.neuro.2009.01.005.

Næstad F, Brittain JE. 2010. Long-term changes in the littoral benthos of a Norwegian subalpine lake following the introduction of the European minnow (Phoxinus phoxinus). Hydrobiologia 642: 71-79. doi: 10.1007/ s10750-010-0160-8.

Okpala COR, Sardo G, Vitale S, Bono G, Arukwe A. 2017. Hazardous properties and toxicological update of mercury: From fish food to human health safety perspective. Critical Reviews in Food Science and Nutrition 58 (12): 1986-2001. doi: 10.1080/10408398.2017.1291491.

Post DM. 2002. Using stable isotopes to estimate trophic position: models, methods, and assumptions. Ecology 83: 705-718. doi: 10.1890/0012-9658(2002)083\%5b0703:USITET\%5d2.0.CO;2.

Power G. 1978. Fish population structure in arctic lakes. Journal of Fisheries Research Board of Canada 35: 53-59. doi: 10.1139/f78-008.

Qvenild T. 2004. Hardangervidda Fiske og Fjelliv. Oslo, Norway. Naturforlaget, $407 \mathrm{p}$.

Qvenild T, Hesthagen T, Fjellheim A. 2020. The freshwater shrimp Gammarus lacustris (Malacostraca, Amphipoda) in lakes on the Hardangervidda mountain plateau, southern Norway: distribution and environmental requirements. Fauna norvegica 40: 1-21. doi: 10.5324/f n.v40i0.3101.

Rognerud S, Borgstrøm R, Qvenild T, Tysse Å. 2003. Ørreten på Hardangervidda. Næringsnett, kvikksølvinnhold, ørekytspredning og klimavariasjoner - følger for fiske og forvaltning. NIVA Rapport 4712:1-68.

Rognerud S, Fjeld E. 2001. Trace element contamination of Norwegian lake sediments. Ambio 30: 11-19. doi: 10.1579/0044-7447-30.1.11.

Rognerud S, Grimalt JO, Rosseland BO, Fernandez P, Hofer R, Lackner R, Lauritzen B, Lien L, Massabuau JC, Vilanova R. 2002. Mercury and organochlorine contamination in brown trout (Salmo trutta) and Arctic charr (Salvelinus alpinus) from high mountain lakes in Europe and the Svalbard archipelago. Water, Air, and Soil Pollution Focus 2: 209-232.

Rosseland BO, Massabuau J-C, Grimalt J, Hofer R, Lackner R, Raddum G, Rognerud S, Vives I. 2001. Fish ecotoxicology, The EMERGE fish sampling manual for live fish. The EMERGE Project (European Mountain lake Ecosystems: Regionalisation, diaGnostic and socioeconomic valuation). http://www.mountain-lakes.org/emerge/www. mountain-lakes.org/emerge/methods/29.pdf

Rosseland BO, Rognerud S, Collen P, Grimalt JO, Vives I, Massabuau J-C, Lackner R, Hofer R, Raddum GG, Fjellheim A, Harriman R, Piñ A B. 2007. Brown trout in Lochnagar: Population and contamination by metals and organic micropollutants. In: Rose NL (ed.). Lochnagar: The Natural History of a Mountain Lake. Springer, Dordrecht. pp. 253-285. doi: 10.1007/1-4020-3986-7. 
Sandlund OT, Næsje TF. 1992. Storørretens betydning i økosystemet. In: Taugbøl T, Skurdal J, Nyberg P. (eds.). Nordisk seminar om forvaltning av storørret. DN-Rapport 4: 6-17. Directorate for Nature Management, Trondheim.

Skjelkvåle BT, Henriksen A. 1998. Vannkjemi, forsuringsstatus og tålegrenser i nasjonalparker; Hardangervidda. NIVA-rapport 3895-98: $1-48$.

Šmilauer P, Lepš J. 2014. Multivariate analysis of ecological data using CANOCO 5. New York. Cambridge University Press, 362 p.

Spencer CN, McClelland BR, Stanford JA. 1991. Shrimp stocking, salmon collapse, and eagle displacement: cascading interactions in the food web of a large aquatic ecosystem. BioScience 41: 14-21. doi: $10.2307 / 1311536$.

Swanson HK, Johnston TA, Leggett WC, Bodaly RA, Doucett RR, Cunjak RA. 2003. Trophic positions and mercury bioaccumulation in rainbow smelt (Osmerus mordax) and native forage fishes in Northwestern Ontario lakes. Ecosystems 6: 289-299. https://www. jstor.org/stable/3658894.

Sømme ID. 1941. Ørretboka. Oslo, Norway. Jakob Dybwad Forlag, 591 p.

Taugbøl T, Hesthagen T, Museth J, Dervo B, Andersen O. 2002. Effekter av ørekytintroduksjoner og utfiskingstiltak - en vurdering av kunnskapsgrunnlaget. NINA oppdragsmelding 753: 1-31.

Ter Braak CJF, Šmilauer P. 2018. Canoco reference manual and user's guide: software for ordination, version 5.10. Ithaca, NY, USA. Microcomputer Power, $496 \mathrm{p}$.

Thaulow J, Borgstrøm R, Heun M. 2014. Genetic analyses of European minnow, Phoxinus phoxinus, in a river system outside its native range indicate multiple invasions from different sources. Fisheries Management and Ecology 21: 75-81. doi: 10.1111/fme.12054.

Vander Zanden JM, Rasmussen JB. 1999. Primary consumer $\delta^{13} \mathrm{C}$ and $\delta^{15} \mathrm{~N}$ and the trophic position of aquatic consumers. Ecology 80: 1395-1404. doi: 10.1890/0012-9658(1999)080\%5b1395:PCCANA\%5d 2.0.CO;2.

Editorial responsibility: Jan Grimsrud Davidsen.

This article is open-access and distributed under the terms of the Creative Commons Attribution 4.0 International license. This permits all noncommercial use, distribution, and reproduction in any medium, provided the original work is properly cited.

(http://creativecommons.org/licenses/by/4.0/). 